\title{
BEHAVIORAL MANAGEMENT IN THE PERSON WITH DEMENTIA
}

\author{
J.E. MORLEY
}

Division of Geriatric Medicine, St. Louis University School of Medicine, 1402 S. Grand Blvd., M238, St. Louis, MO 63104, Email: morley@ slu.edu

The early recognition of cognitive impairment is imperative, as cognitive changes are often associated with a variety of behavioral changes $(1,2)$. Many persons with amnestic mild cognitive impairment (MCI) often develop depression which can aggravate the cognitive impairment $(3,4)$. Persons with Alzheimer's disease often have concurrent apathy and/or depression (5-7). Behavioral disorders account for $11 \%$ of hospitalizations in persons with dementia (8-10). Early recognition of these occurrences and referral to a geriatrician is an essential component for the appropriate early management of the individual (11-16). For this reason, it is essential to increase awareness of the general practitioner and their ability to diagnose both early cognitive impairment and depression $(17,18)$. Both the Montreal Cognitive Assessment (MoCA) and the Saint Louis University Mental Status (SLUMS) examination are useful tools for diagnosing MCI $(19,20)$. The Patient Health Questionnaire-9 (PHQ-9) is replacing the Geriatric Depression Scale as the diagnostic test of choice for depression, particularly as the MDS 3.0 has developed a validated version that can be used in cognitively impaired individuals $(21,22)$.

An important behavioral change in persons with dementia is the alterations in feeding behavior (23-26). Early on there may be an increase in food intake, but as the dementia progresses persons with dementia classically become anorectic and lose weight (27-29). Screening with the Mini Nutritional Assessment (MNA) to allow early intervention is essential (3034). Alzheimer's patients often develop paranoia and may perceive that they are being poisoned (35). Other treatable causes of anorexia should be explored in all persons with dementia who are losing weight (36). Caloric supplements between meals, as well as access to enjoyable finger food are an important approach to maintain weight $(37,38)$. Day care at green care farms helps to maintain weight (39). In the United States tube feeding is over utilized in persons with dementia (40). A person with dementia can take up to 45 minutes to feed (41). Persons with depressive symptoms are at extremely high risk of weight loss (42-45). The loss of weight in demented patients increases the chance of them developing frailty (4650). Frailty can accelerate cognitive decline (51-54, 56-58). When frailty is combined with dementia, the risk of all cause mortality is increased (59).

Changes in sleep behavior commonly occur with dementia $(60,61)$. Persons with Alzheimer's disease tend to have phase advancement, resulting in being awake at night when others are normally going to sleep (62). Bright light (2000 lux) given in the morning can reverse this abnormality and can reduce agitated behavior (63). Sleeping abnormalities, especially sleep apnea, have been associated with rapid cognitive decline (64, 65).

A number of neuropsychiatric symptoms are seen in dementia. These include psychotic symptoms (such as hallucinations, delusions, illusions and paranoia) and hyperactivity (aggression, mania, agitation, irritation), besides the depressive/anxiety type behaviors. These behaviors are present in over two-thirds of residents with dementia in the nursing homes (66).

Disinhibition is another behavior that is common in persons with dementia, especially those with Lewy-Body dementia. Disinhibition often leads to abnormal sexual behaviors (67). Public masturbation, sexual aggression to others and inappropriate verbal sexual comments are all not rare in the demented person. Use of progestagenic drugs to treat sexual behaviors is not recommended because of the high propensity to cause deep vein thrombosis (68).

Persons with dementia are at high risk of developing delirium (69-72). Changes in behaviors need to be recognized early and the patient carefully examined for treatable causes with delirium (73). Management of delirium requires high quality of nursing, and avoidance of physical and chemical restraints (74-77).

Pain is very common in older persons (78-80). Persons with dementia cannot always communicate that they are in pain. Appropriate pain medication should be instituted in any agitated person when it is uncertain whether or not they are in pain. Memantine has been shown to have a small effect on agitated behavior in some but not all studies (81). It is possible that this effect is due to its ability to block NMDA glutamate receptors. There is increased activity of the NMDA glutamate receptors in persons with chronic pain and blocking these receptors has been shown to reduce pain (82).

Cholinesterase inhibitors have been reported to decrease agitated behavior, but the quality of these studies has been variable $(83,84)$. These drugs also slow cognitive decline, but the clinical significance is small (85). There appears to be a subset of individuals who have much better responses to cholinesterase inhibitors, than do the majority of demented individuals.

Antipsychotic medications should be used in persons with hallucinations, delusions, illusions and paranoia as well as in those with documented schizophrenia or other psychoses. Antipsychotic medicines have not been shown statistically to improve difficult behaviors in other demented individuals (86). In persons with dementia, besides producing tardive dyskinesia, acute dystonia and Parkinson's like symptoms, antipsychotics increase mortality, stroke, myocardial infarction, diabetes 


\section{BEHAVIORAL MANAGEMENT IN THE PERSON WITH DEMENTIA}

mellitus, cataracts and hip fractures (87-90). For these reasons antipsychotics should be avoided in persons with dementia.

Exercise has been shown to slow cognitive decline and improve function in persons with dementia (91-93). A number of studies have shown that both aerobic and resistance exercise reduce episodes of agitated behavior (94-97). Exercise is as effective as pharmaceutical agents and behavioral therapy in reducing depression (98). In addition, exercise improves sleep $(99,100)$. All persons with dementia should be enrolled in an exercise program for 30 minutes at least 3 times per week.

In many cases agitation is precipitated by well meaning gestures from family or staff that are misinterpreted by the demented individual. Taking persons with dementia to a novel environment can be very stressful and precipitate agitated behaviors (101). There is increasing evidence that structured behavioral therapy can improve functioning and decrease agitation in older persons with dementia. Cognitive Stimulation Therapy has been shown to improve memory and self-reported quality of life and well being (102-104).

Resistiveness to care is a particular problem in dementia, especially in the nursing home settings (105). A resistiveness to care scale has been developed and can be helpful in recognizing persons who will need a focus on this problem among the nurses' aides providing care for the individual (106). Caregiver singing has been found to reduce resistance to care in one small study (107). Use of low doses of short acting benzodiazepines may be necessary to help overcome the resistiveness.

Excessive continuous vocalizations are occasionally present in persons with dementia. Behavioral modification using a hearing amplifier to provide feedback to the individual is occasionally useful. This behavior is considered by some a form of depression and it has been found to respond to electroconvulsive therapy.

Sundowning is increased confusion or restlessness that occurs in the early evening in persons with dementia (108). There are many potential causes and identification of the cause is often the solution to the problem. As previously noted, alteration of circadian rhythm is persons with dementia can lead to an increase in activity later in the day. Shadows can produce illusionary objects that can be disturbing to the demented person, particularly if they have visual disturbances. Hunger, hypoglycemia, hyperglycemia and postprandial hypotension can all trigger agitation around the mealtime $(109,110)$. Fear of darkness can also trigger behavioral problems.

There are numerous different causes of behavioral problems in older persons with dementia. Identifying the cause of the problem is essential to appropriate management. In general, exercise and behavioral therapies are preferable to pharmacological approaches to the management. All older persons with end stage dementia and difficult behaviors should be enrolled in an end-of-life or hospice program to help enhance their quality of life (111-114). As proposed by the IAGG/WHO position paper on nursing homes there is a high need for research and education on behavioral interventions for agitated behavior $(115,116)$.

\section{References}

1. Vance DE, Fazeli PL, Kaur J, Pearce P, McGuinness T. Neuropsychology and cognitive health in healthy older adults: a brief overview for psychiatric nurses. J Psychosoc Nurs Ment Health Serv. 2012 Jun;50(6):30-7; quiz 46-7. doi: 10.3928/02793695-20120508-03. Epub 2012 May 18. PubMed PMID: 22589228.

2. Butler D, Kowall NW, Lawler E, Michael Gaziano J, Driver JA. Underuse of diagnostic codes for specific dementias in the Veterans Affairs New England healthcare system. J Am Geriatr Soc. 2012 May;60(5):910-5. doi: 10.1111/j.15325415.2012.03933.x. PubMed PMID: 22587853.

3. Morley JE. Dementia-related agitation. J Am Med Dir Assoc 2011;12:611-612.e2.

4. Panza F, Frisardi V, Capurso C, et al. Late-life depression, mild cognitive impairment, and dementia: Possible continuum? Am J Geriatr Psychiatry 2010;18:98116.

5. Arbus C, Gardette V, Cantet CE, et al; REAL.FR Group. Incidence and predictive factors of depressive symptoms in Alzheimer's disease: The REAL.FR study. J Nutr Health Aging 2011;15:609-617.

6. Hölltä EH, Laakkonen ML, Laurila JV, et al. Apathy: Prevalence, associated factors, and prognostic value among frail, older inpatients. J Am Med Dir Assoc 2012;May 8 [Epub ahead of print]

7. Morley JE. Depression in nursing home residents. J Am Med Dir Assoc 2010;11:301303.

8. Voisin T, Andrieu S, Cantet C, Vellas B; REAL.FR Group. Predictive factors of hospitalizations in Alzheimer's disease: a two-year prospective study in 686 patients of the REAL.FR study. J Nutr Health Aging 2010;14:288-291.

9. Voisin T, Sourdet S, Cantet C, Andrieu S, Vellas B. Descriptive analysis of hospitalizations of patients with Alzheimer's disease: two-year prospective study of 686 patients from the REAL.FR study. J Nutr Health Aging 2009;13:890-892.

10. Soto ME, Andrieu S, Arbus C, et al. Rapid cognitive decline in Alzheimer's disease. Consensus paper. J Nutr Health Aging 2008;12:703-713.

11. Morley JE. Editorial: Can we improve care for patients with dementia? J Nutr Health Aging 2011;15:523-525.

12. Al-Aloucy MJ, Cotteret R, Thomas $\mathrm{P}$, et al. Unawareness of memory impairment and behavioral abnormalities in patients with Alzheimer's disease: relation to professional health care burden. J Nutr Health Aging 2011;15:356-360.

13. Pedrosa H, De Sa A, Guerreiro M, et al. Functional evaluation distinguishes MCI patients from healthy elderly people-the ADCS/MCI/ADL scale. J Nutr Health Aging 2010;14:703-709.

14. Pimouguet C, Lavaud T, Dartigues JF, Helmer C. Dementia case management effectiveness on health care costs and resource utilization: A systematic review of randomized controlled trials. J Nutr Health Aging 2010;14:669-676.

15. Villars H, Oustric S, Andrieu S, et al. The primary care physician and Alzheimer's disease: an international position paper. J Nutr Hlth Aging 2010;14:110-120.

16. Rountree SD, Chan W, Pavlik VN, Darby EJ, Doody RS. Factors that influence survival in a probable Alzheimer disease cohort. Alzheimers Res Ther. 2012 May 17;4(3):16. [Epub ahead of print] PubMed PMID: 22594761.

17. Schoenmakers B, Buntinx F, De Lepeleire J. The primary care physician and Alzheimer's disease: An international position paper. J Nutr Health Aging 2011;15:595-596

18. Kaduszkiewicz H, Zimmerman T, van den Bussche H, et al; AgeCoDe Study Group. Do general practitioners recognize mild cognitive impairment in their patients? J Nutr Health Aging 2010;14:697-702.

19. Tariq SH, Tumosa N, Chibnall JT, et al. Comparison of the Saint Louis University mental status examination and the mini-mental state examination for detecting dementia and mild neurocognitive disorder-a pilot study. Am J Geriatr Psychiatry 2006; 14:900-910.

20. Freitas S, Simões MR. Alves L, et al. Montreal Cognitive Assessment (MoCA): Validation study for vascular dementia. J Int Neuropsychol Soc 2012;8:1-10.

21. Kroenke K, Spitzer RL, Williams JB, Löwe B. The patient health questionnaire somatic, anxiety, and depressive symptoms scales: A systematic review. Gen Hosp Psychiatry 2010;32:345-359.

22. Saliba D, DiFilippo S, Edelen MO, et al. Testing the PHQ-9 interview and observational versions (PHQ-9 OV) for MDS 3.0. J Am Med Dir Assoc 2012;13: (Sept issue)

23. Salvà $\mathrm{A}$, Andrieu $\mathrm{S}$, Fernandez $\mathrm{E}$, et al. Health and nutrition promotion program for patients with dementia (NutriAlz): Cluster randomized trial. J Nutr Health Aging 2011;15:822-830.

24. Bourdel-Marchasson I. How to improve nutritional support in geriatric institutions. J Am Med Dir Assoc 2010;11:13-20.

25. Gillette Guyonnet S, Abellan van Kan G, Alix E, et al; International Academy on Nutrition and Aging Expert Group. IANA (International Academy on Nutrition and Aging) Expert Group: Weight loss and Alzheimer's disease. J Nutr Health Aging 2007;11:38-48.

26. White HK, McConnell ES, Bales CW, Kuchibhatla M. A 6-month observational 


\section{JNHA: CLINICAL NEUROSCIENCES}

study of the relationship between weight loss and behavioral symptoms in institutionalized Alzheimer's disease subjects. J Am Med Dir Assoc 2004;5:89-97.

27. Belmin J. Expert Panel and Organisation Committee. Practical guidelines for the diagnosis and management of weight loss in Alzheimer's disease: A consensus from appropriateness ratings of a large expert panel. J Nutr Health Aging 207;11:33-37

28. Wang SY. Weight loss and metabolic changes in dementia. J Nutr Health Aging 2002;6:201-205.

29. Landi F, Russo A, Liperoti R, et al. Anorexia, physical function, and incident disability among the frail elderly population: Results from the ilSIRENTE study. J Am Med Dir Assoc 2010;11:268-274.

30. Orsitto G. Different components of nutritional status in older inpatients with cognitive impairment. J Nutr Health Aging 2012;16:468-471.

31. Khater MS, Abouelezz NF. Nutritional status in older adults with mild cognitive impairment in elderly homes in Cairo, Egypt. J Nutr Health Aging 2011;15:104-108.

32. Kaiser MJ, Bauer JM, Ramsch C, et al. Validation of the Mini Nutritional Assessment short-form (MNA-SF): A practical tool for identification of nutritional status. J Nutr Health Aging 2009;13:782-788.

33. Vellas B, Villars H, Abellan G, et al. Overview of the MNA - its history and challenges. J Nutr Health Aging 2006;10:456-463.

34. Young AM, Kidston S, Banks MD, Mudge AM, Isenring EA. Malnutrition screening tools: Comparison against two validated nutrition assessment methods in older medical inpatients. Nutrition. 2012 Aug 1. [Epub ahead of print] PubMed PMID: 22858197.

35. Morley JE, Kraenzle D. Causes of weight loss in a community nursing home. J Am Geriatr Soc 1994;42:583-585.

36. Morley JE. Weight loss in older persons: New therapeutic approaches. Curr Pharm Des 2007;13:3637-3647.

37. Wilson MM, Purushothaman R, Morley JE. Effect of liquid dietary supplements on energy intake in the elderly. Am J Clin Nutr 2002;75:944-947.

38. Donini LM, Dominguez LJ, Barbagallo M, et al. Senile anorexia in different geriatric settings in Italy. J Nutr Health Aging 2011;15:775-781.

39. De Bruin SR, Oosting SJ, Tobi H, et al. Day care at green care farms: A novel way to stimulate dietary intake of community-dwelling older people with dementia? J Nutr Health Aging 2010;14:352-57.

40. Volicer L. Tube feeding in Alzheimer's disease is avoidable. J Nutr Health Aging 1998:2:122-123.

41. Schnelle JF, Bertrand R, Hurd D, et al. The importance of standardized observations to evaluate nutritional care quality in the survey process. J Am Med Dir Assoc 2009; 10:568-574.

42. German L, Kahana C, Rosenfeld V, et al. Depressive symptoms are associated with food insufficiency and nutritional deficiencies in poor community-dwelling elderly people. J Nutr Health Aging 2011;15:3-8.

43. Torres SJ, McCabe M, Nowson CA. Depression, nutritional risk and eating behaviour in older caregivers. J Nutr Health Aging 2010;14:442-448.

44. Damiàn J, Pastor-Barriuso R, Valderrama-Gama E. Descriptive epidemiology of undetected depression in institutionalized older people. J Am Med Dir Assoc 2010;11:312-319.

45. Morley JE. Weight loss in older persons: New therapeutic approaches. Curr Pharm Des 2007; 13:3637-3647

46. Dramé M, Novella JL, Jolly D, et al. Rapid cognitive decline, one-year institutional admission and one-year mortality: Analysis of the ability to predict and inter-tool agreement of four validated clinical frailty indexes in the SAFEs cohort. J Nutr Health Aging 2011;15:699-705.

47. Abellan van Kan G, Rolland Y, Bergman H, et al. The I.A.N.A. Task Force on frailty assessment of older people in clinical practice. J Nutr Health Aging 2008;12:29-37.

48. Abellan van Kan G, Rolland YM, Morley JE, Vellas B. Frailty: Toward a clinical definition. J Am Med Dir Assoc 2008;9:71-72.

49. Rockwood K, Abeysundera MJ, Mitnitski A. How should we grade frailty in nursing home patients? J Am Med Dir Assoc 2007;8:595-603.

50. Sourdet S, Rougé-Bugat ME, Vellas B, Forette F. Frailty and aging. J Nutr Health Aging 2012;16:283-284

51. Morley JE. Anorexia, weight loss, and frailty. J Am Med Dir Assoc 2010;11:225228.

52. Gobbens RJ, van Assen MA, Luijkx KG, et al. The Tilburg Frailty Indicator: Psychometric properties. J Am Med Dir Assoc 2010;11:344-355.

53. Panza F, Solfrizzi V, Frisardi V, et al. Different models of frailty in predementia and dementia syndromes. J Nutr Health Aging 2011;15:711-719.

54. Gobbens RJ, van Assen MA, Luijkx KG, et al. Determinants of frailty. J Am Med Dir Assoc 2010;11:356-364.

55. Yassuda MS, Lopes A, Cachioni M, et al. Frailty criteria and cognitive performance are related: Data from the FIBRA Study in Ermelino Matarazzo, São Paulo, Brazil. J Nutr Health Aging 2012;16:55-61.

56. Mitnitski A, Fallah N, Rockwood MR, Rockwood K. Transitions in cognitive status in relation to frailty in older adults: A comparison of three frailty measures. J Nutr Health Aging 2011;15:863-867.

57. Gobbens RJ, Luijkx KG, Wijnen-Sponselee MT, Schols JM. In search of an integral conceptual definition of frailty: Opinions of experts. J Am Med Dir Assoc
2010;11:338-343

58. Shatenstein B. Frailty and cognitive decline: links, mechanisms and future directions J Nutr Health Aging 2011;15:665-666.

59. Matusik P, Tomaszewski K, Chmielowska K, et al. Severe frailty and cognitive impairment are related to higher mortality in 12-month follow-up of nursing home residents. Arch Gerontol Geriatr 2012;55:22-24

60. Gabelle A, Dauvilliers Y. Editorial: Sleep and dementia. J Nutr Health Aging 2010;14:201-202.

61. Zeitzer DR, Friedman L, Noda A, et al. Non-pharmacologic management of sleep disturbance in Alzheimer's disease. J Nutr Health Aging 2010;14:203-206.

62. Wu YH, Swaab DF. Disturbance and strategies for reactivation of the circadian rhythm system in aging and Alzheimer's disease. Sleep Med 2007;8:623-636.

63. Royer M, Ballentine NH, Eslinger PJ, et al. Light therapy for seniors in long term care. J Am Med Dir Assoc 2012;13:100-102.

64. Bombois S, Derambure P, Pasquier F, Monaca C. Sleep disorders in aging and dementia. J Nutr Health Aging 2010;14:212-217.

65. Resnick HE, Phillips B. Documentation of sleep apnea in nursing homes: United States 2004. J Am Med Dir Assoc 2008;9:260-264.

66. Gonfrier S, Andrieu S, Renaud D, Vellas B, Robert PH. Course of neuropsychiatric symptoms during a 4-year follow up in the REAL-FR cohort. J Nutr Health Aging 2012;16:134-137

67. Hajjar RR, Kamel HK. Sexuality in the nursing home: Part 1: Attitudes and barriers to sexual expression. J Am Med Dir Assoc 2004;5(2 Suppl):S42-S47.

68. Kamel HK, Hajjar RR. Sexuality in the nursing home, part 2: Managing abnormal behavior-legal and ethical issues. J Am Med Dir Assoc 2004;5(2 Suppl):S48-S52.

69. Eeles E, Rockwood K. Delirium in the long-term care setting: Clinical and research challenges. J Am Med Dir Assoc 2008;9:157-161.

70. Flaherty JH, Shay K, Weir C, et al. VA Delirium Working Group. The development of a mental status vital sign for use across the spectrum of care. J Am Med Dir Assoc 2009;10:379-380.

71. Bellelli G, Speciale S, Morghen S, et al. Are fluctuations in motor performance a diagnostic sign of delirium? J Am Med Dir Assoc 2011;12:578-583.

72. Jones RN, Kiely DK, Marcantonio ER. Prevalence of delirium on admission to postacute care is associated with a higher number of nursing home deficiencies. J Am Med Dir Assoc 20120;11:253-256.

73. Voyer P, Richard S, McCusker J, et al. Detection of delirium and its symptoms by nurses working in a long term care facility. J Am Med Dir Assoc 2012;13:264-271.

74. Flaherty JH, Tariq SH, Raghavan S, et al. A model for managing delirious older inpatients. J Am Geriatr Soc 2003;51:1031-1035.

75. Flaherty JH, Rudolph J, Shay K, et al. Delirium is a serious and under-recognized problem: Why assessment of mental status should be the sixth vital sign. J Am Med Dir Assoc 2007;8:273-275.

76. Flaherty JH, Steele DK, Chibnall JT, et al. An ACE unit with a delirium room may improve function and equalize length of stay among older delirious medical inpatients. J Gerontol A Biol Sci Med Sci 2010;65:1387-1392.

77. Flaherty JH. The evaluation and management of delirium among older persons. Med Clin North Am 2011;95:555-577.

78. Lapane KL, Quilliam BJ, Chow W, Kim M. The association between pain and measures of well-being among nursing home residents. J Am Med Dir Assoc 2012;13:344-349.

79. Kamel HK, Phlavan M, Malekgoudarzi B, Gogel P, Morley JE. Utilizing pain assessment scales increases the frequency of diagnosing pain among elderly nursing home residents. J Pain Symptom Manage 2001;21:450-455.

80. Morley JE. Pain - “God's megaphone.”J Am Med Dir Assoc 2012;13:316-318.

81. Fox C, Crugel M, Maidment I, et al. Efficacy of memantine for agitation in Alzheimer's dementia: A randomised double-blind placebo controlled trial. PLoS One 2012;7:e35185. Epub 2012 May 2.

82. Collins S, Sigtermans MJ, Dahan A, Zuurmond WW, Perez RS. NMDA receptor antagonists for the treatment of neuropathic pain. Pain Med 2010;11:1726-1742.

83. Rodda J, Morgan S, Walker Z. Are cholinesterase inhibitors effective in the management of the behavioral and psychological symptoms of dementia in Alzheimer's disease? A systematic review of randomized, placebo-controlled trials of donepezil, rivastigmine and galantamine. Int Psychogeriatr 2009;21:813-824.

84. Pinto T, Lanctot KL, Herrmann N. Revisiting the cholinergic hypothesis of behavioral and psychological symptoms in dementia of the Alzheimer's type. Ageing Res Rev 2011;10:404-412.

85. Howard R, McShane R, Lindesay J, et al. Donepezil and memantine for moderate-tosevere Alzheimer's disease. N Engl J Med 2012;366:893-903.

86. Cornegé-Blokland E, Kleijer BC, Hertogh CM, van Marum RJ. Reasons to prescribe antipsychotics for the behavioral symptoms of dementia: A survey in Dutch nursing homes among physicians, nurses, and family caregivers. J Am Med Dir Assoc 2012;13:80.e1-6.

87. Howard P, Twycross R, Shuster J, et al. Antipsychotics. J Pain Symptom Manage 2011;41:956-965.

88. Mittal V, Kurup L, Williamson D, Muralee S, Tampi RR. Risk of cerebrovascular adverse events and death in elderly patients with dementia when treated with antipsychotic medications: A literature review of evidence. Am J Alzheimers Dis 


\section{BEHAVIORAL MANAGEMENT IN THE PERSON WITH DEMENTIA}

Other Demen 2011;26:10-28.

89. Jalbert JJ, Eaton CB, Miller SC, Lapane KL. Antipsychotic use and the risk of hip fracture among older adults afflicted with dementia. J Am Med Dir Assoc 2010;11:120-127.

90. Jalbert JJ, Daiello LA, Eaton CB, et al. Antipsychotic use and the risk of diabetes in nursing home residents with dementia. Am J Geriatr Pharmacother 2011;9:153-163.

91. Leone E, Deudon A, Robert P. Physical activity, dementia and BPSD. J Nutr Health Aging 2008;12:457-460.

92. Rolland Y, Abellan van Kan G, Vellas B. Physical activity and Alzheimer's disease: from prevention to therapeutic perspectives. J Am Med Dir Assoc 2008;9:390-405.

93. Morley JE. J Am Med Dir Assoc 2008;9:139-146. Managing persons with dementia in the nursing home: High touch trumps high tech. J Am Med Dir Assoc 2008;9:139146.

94. Aman E, Thomas DR. Supervised exercise to reduce agitation in severely cognitively impaired persons. J Am Med Dir Assoc 2009;10:271-276.

95. Volicer L, Simard J, Pupa JH, Medrek R, Riordan ME. Effects of continuous activity programming on behavioral symptoms of dementia. J Am Med Dir Assoc 2006; 7:426-431.

96. Lam LC, Chau RC, Wong BM, et al. A 1-year randomized controlled trial comparing mind body exercise (Tai Chi) with stretching and toning exercise on cognitive function in older Chinese adults at risk of cognitive decline. J Am Med Dir Assoc 2012;May 11 [Epub ahead of print].

97. Snyder A, Colvin B, Gammack JK. Pedometer use increases daily steps and functional status in older adults. J Am Med Dir Assoc 2011;12:590-594.

98. Mead GE, Morley W, Campbell P, et al. Exercise for depression. Cochrane Database Syst Rev 2009;Jul 8;(3):CD004366.

99. Seitz DP, Brisbin S, Herrmann N, et al. Efficacy and feasibility of nonpharmacological interventions for neuropsychiatric symptoms of dementia in long term care: A systematic review. J Am Med Dir Assoc 2012;Feb 16 [Epub ahead of print]

100. Lira FS, Pimentel GD, Santos RV, et al. Exercise training improves sleep pattern and metabolic profile in elderly people in a time-dependent manner. Lipids Health Dis 2011;10:1-6.

101. Benoit M, Arbus C, Blanchard F, et al. Professional consensus on the treatment of agitation, aggressive behaviour, oppositional behaviour and psychotic disturbances in dementia. J Nutr Health Aging 2006;10:410-415.

102. Aguirre E, Hoare Z, Streater A, et al. Cognitive stimulation therapy (CST) for people with dementia-who benefits most? Int J Geriatr Psychiatry 2012;10.doi:10.1002/gps3823 [Epub ahead of print].

103. Orrell M, Woods B, Spector A. Should we use individual cognitive stimulation therapy to improve cognitive function in people with dementia? Brit Med J 2012;344:e633. Doi: 10.1136/bmj.e633.

104. Woods B, Aguirre E, Spector AE, Orrell M. Cognitive stimulation to improve cognitive functioning in people with dementia. Cochrane Database Syst Rev 2012;Feb 15;2:CD005562.

105. Volicer L, Bass EA, Luther SL. Agitation and resistiveness to care are two separate behavioral syndromes of dementia. J Am Med Dir Assoc 2007;8:527-532.

106. Mahoney EK, Hurley AC, Volicer L, et al. Development and testing of the Resistiveness to Care Scale. Res Nurs Health 1999;22:27-38.

107. Hammar LM, Emami A, Götell E, Engström G. The impact of caregivers's singing on expressions of emotion and resistance during morning care situations in persons with dementia: An intervention in dementia care. J Clin Nurs 2011;20:969-978.

108. Sharer J. Tackling sundowning in a patients with Alzheimer's disease. Medsurg Nurs 2008; 17:27-29.

109. Migdal A, Yarandi SS, Smiley D, Umpierrez GE. Update on diabetes in the elderly and in nursing home residents. J Am Med Dir Assoc 2011;12:627-632.e2.

110. Morley JE. Hypertension: Is it overtreated in the elderly? J Am Med Dir Assoc 2010;11:147-152

111. Carlson MD, Lim B, Meier DE. Strategies and innovative models for delivering palliative care in nursing homes. J Am Med Dir Assoc 2011;12:91-98.

112. Morley JE. End-of-life care in the nursing home. J Am Med Dir Assoc 2011;12:7783.

113. Volicer L. Goals of care in advanced dementia: Quality of life, dignity and comfort. J Nutr Health Aging 2007;11:481.

114. Gove D, Sparr S, Dos Santos Bernardo AM, et al. Recommendations on end-of-life care for people with dementia. J Nutr Hlth Aging 2010;14:136-139.

115. Rolland Y, Aquino JP, Andrieu S, et al. Identification of the main domains for quality of care and clinical research in nursing homes. J Nutr Health Aging 2011;15:410-424.

116. Tolson D, Rolland Y, Andrieu S, et al; The International Association of Gerontology and Geriatrics/World Health Organization/Society Française de Gérontologie et de Gériatrie Task Force. International Association of Gerontology and Geriatrics: A global agenda for clinical research and quality of care in nursing homes. J Am Med Dir Assoc 2011;12:184-189. 